\title{
Safety profiles of sodium-glucose co-transporter 2 inhibitors in Japanese patients with diabetes mellitus: A literature review and meta-analysis
}

Junichi Mukai ( $\nabla$ mukai11@kitasato-u.ac.jp)

Division of Clinical Pharmacy (Laboratory of Clinical Pharmacy Education) and Research and Education Center for Clinical

Pharmacy, School of Pharmacy, Kitasato University https://orcid.org/0000-0003-0441-8968

Shinya Kanno

Division of Clinical Pharmacy (Laboratory of Clinical Pharmacy Education) and Research and Education Center for Clinical

Pharmacy, School of Pharmacy, Kitasato University

\section{Rie Kubota}

Division of Clinical Pharmacy (Laboratory of Clinical Pharmacy Education) and Research and Education Center for Clinical Pharmacy, School of Pharmacy, Kitasato University

\section{Systematic Review}

Keywords: SGLT2 inhibitors, systematic review, diabetes mellitus, meta-analysis

Posted Date: March 23rd, 2021

DOI: https://doi.org/10.21203/rs.3.rs-353578/v1

License: @) (1) This work is licensed under a Creative Commons Attribution 4.0 International License. Read Full License

Version of Record: A version of this preprint was published at Scientific Reports on June 29th, 2021. See the published version at https://doi.org/10.1038/s41598-021-92925-2. 


\section{Abstract}

We conducted a literature review and meta-analysis of safety profiles of sodium-glucose co-transporter 2 (SGLT2) inhibitors in Japanese patients with diabetes mellitus (DM). The electronic databases MEDLINE, CENTRAL, and Ichushi-web were searched for studies from their inception through to August 2019 and there was no language restriction. Trials were included in the analysis if they were randomized controlled trials (RCTs) (1) comparing the effects of SGLT2 inhibitors with a placebo in Japanese patients with $\mathrm{DM} \leq 18$ years, and (2) reporting HbA1c and at least one adverse event. We calculated risk ratios with $95 \% \mathrm{Cl}$ and used a random-effects model. Twenty-two out of the 765 RCTs retrieved were ultimately included in the present review, and only one RCT included patients with type 1 DM. The durations of RCTs ranged between 4 and 24 weeks. In comparisons with a placebo, SGLT2 inhibitors were associated with similar risks of hypoglycemia, urinary tract infection, genital infection, hypovolemia, and fracture. The outcomes of treatments with SGLT2 inhibitors among Japanese patients with DM suggest favorable safety profiles. However, further evidence from studies with a longer duration, involving more diverse populations, or including individual SGLT2 inhibitors is needed to resolve the limitations of the present study.

\section{Introduction}

Sodium-glucose co-transporter 2 (SGLT2) inhibitors are novel oral hypoglycemic agents that exert beneficial effects on glycemic control and weight loss in patients with type 1 and 2 diabetes mellitus (DM) ${ }^{1-3}$. To date, SGLT2 inhibitors have been shown to exert these effects between different races/ethnicities. For example, recent randomized controlled trials (RCTs), which included approximately $80 \%$ Caucasians, showed favorable effects on glycemic control and weight loss as well as in Asians ${ }^{4-6}$. Furthermore, meta-analyses recently showed that the effects of SGLT2 inhibitors on not only glycemic control and weight loss, but also lipid profiles were similar between Asian and non-Asian patients ${ }^{7,8}$.

In contrast, previous findings on the safety profiles of SGLT2 inhibitors between different races/ethnicities have been inconsistent; one meta-analysis showed that the safety profiles of SGLT2 inhibitors differed between Asian and non-Asian patients. SGLT2 inhibitors increased the risk of urinary tract infection (UTI) in non-Asian patients with type 2 DM, but were associated with a similar risk of UTI as a placebo in Asian patients with type $2 \mathrm{DM}^{7}$. This study also indicated that the risk of hypoglycemia was higher in non-Asian patients with type 2 DM who were treated with SGLT2 inhibitors than in Asian patients with type $2 \mathrm{DM}^{7}$. Another study that focused on racial differences found that the risk of cough was higher in East Asian patients who are treated with angiotensin-converting enzyme inhibitors than in Caucasian patients ${ }^{9}$. Based on these findings, we hypothesized that the safety profiles of SGLT2 inhibitors in patients with DM depend on racial differences. Moreover, to the best of our knowledge, no meta-analyses exist on the safety profiles of SGLT2 inhibitors in Japanese patients with DM. Therefore, we herein conducted a systematic review and meta-analysis to summarize the available literature and appraise the safety profiles of SGLT2 inhibitors in Japanese patients with DM.

\section{Results}

We identified 765 studies in the database search. One hundred and eighty-one full texts were retrieved after the removal of duplications and screening of titles and abstracts. Twenty-two RCTs were ultimately included in our review. Supplementary Figure $\mathrm{S} 1$ shows the process used to identify eligible RCTs ${ }^{10-31}$ following PRISMA ${ }^{32}$. Table 1 shows the characteristics of RCTs included in the meta-analysis. Only one study included patients with type $1 \mathrm{DM}^{18}$. Six types of SGLT2 inhibitors were collected: canagliflozin (CANA), dapagliflozin (DAPA), empagliflozin (EMPA), ipragliflozin (IPRA), luseogliflozin (LUSEO), and tofogliflozin (TOFO). The durations of RCTs ranged between 4 and 24 weeks. Since one study had data on safety profiles at weeks 24 and $52{ }^{17}$, we extracted the former data before the up-titration of EMPA was initiated. All trials were published in English. 
Table 1

Characteristics of 22 randomized controlled trials included in the meta-analysis

\begin{tabular}{|c|c|c|c|c|c|c|c|c|c|c|}
\hline Author & $\begin{array}{l}\text { Types } \\
\text { of } \\
\text { DM }\end{array}$ & $\begin{array}{l}\text { Concomitant } \\
\text { medications }\end{array}$ & $\begin{array}{l}\text { Doses } \\
\text { [mg/day] }\end{array}$ & $\mathbf{N}$ & $\begin{array}{l}\text { Duration } \\
\text { weeks }\end{array}$ & $\begin{array}{l}\text { Age } \\
\text { year }\end{array}$ & $\begin{array}{l}\text { HbA1c } \\
\text { NGSP, } \\
\%\end{array}$ & $\begin{array}{l}\text { BMI } \\
\mathrm{kg} / \mathrm{m}^{2}\end{array}$ & $\begin{array}{l}\text { eGFR } \\
\mathrm{mL} / \mathrm{min} / 1.73 \\
\mathrm{~m}^{2}\end{array}$ & $\begin{array}{l}\text { Jadad } \\
\text { Scale }\end{array}$ \\
\hline \multirow[t]{5}{*}{$\begin{array}{l}\text { Inagaki } \\
201310\end{array}$} & $\begin{array}{l}\text { Type } \\
2\end{array}$ & None & $\begin{array}{l}\text { CANA } 50 \\
\text { mg }\end{array}$ & 82 & 12 & 57.4 & 8.13 & 25.11 & 83.5 & 5 \\
\hline & & & $\begin{array}{l}\text { CANA } \\
100 \mathrm{mg}\end{array}$ & 74 & & 57.7 & 8.05 & 25.61 & 86.9 & \\
\hline & & & $\begin{array}{l}\text { CANA } \\
200 \mathrm{mg}\end{array}$ & 76 & & 57.0 & 8.11 & 25.51 & 83.8 & \\
\hline & & & $\begin{array}{l}\text { CANA } \\
300 \mathrm{mg}\end{array}$ & 75 & & 57.1 & 8.17 & 25.89 & 86.9 & \\
\hline & & & Placebo & 75 & & 57.7 & 7.99 & 26.41 & 83.0 & \\
\hline \multirow[t]{3}{*}{$\begin{array}{l}\text { Inagaki } \\
2014^{11}\end{array}$} & $\begin{array}{l}\text { Type } \\
2\end{array}$ & None & $\begin{array}{l}\text { CANA } \\
100 \mathrm{mg}\end{array}$ & 90 & 24 & 58.4 & 7.98 & 25.59 & 81.4 & 5 \\
\hline & & & $\begin{array}{l}\text { CANA } \\
200 \mathrm{mg}\end{array}$ & 88 & & 57.4 & 8.04 & 25.43 & 87.2 & \\
\hline & & & Placebo & 93 & & 58.2 & 8.04 & 25.85 & 84.7 & \\
\hline \multirow[t]{2}{*}{$\begin{array}{l}\text { Inagaki } \\
2016^{12}\end{array}$} & $\begin{array}{l}\text { Type } \\
2\end{array}$ & Insulin & $\begin{array}{l}\text { CANA } \\
100 \mathrm{mg}\end{array}$ & 76 & 16 & 59.7 & 8.89 & 26.88 & 83.8 & 5 \\
\hline & & & Placebo & 70 & & 56.1 & 8.85 & 25.99 & 86.1 & \\
\hline \multirow[t]{2}{*}{$\begin{array}{l}\text { Kadowaki } \\
2017^{13}\end{array}$} & $\begin{array}{l}\text { Type } \\
2\end{array}$ & Teneligliptin & $\begin{array}{l}\text { CANA } \\
100 \mathrm{mg}\end{array}$ & 70 & 24 & 58.4 & 8.18 & 25.53 & 84.7 & 5 \\
\hline & & & Placebo & 68 & & 56.0 & 7.87 & 26.44 & 83.9 & \\
\hline \multirow[t]{2}{*}{$\begin{array}{l}\text { Araki } \\
2016^{14}\end{array}$} & $\begin{array}{l}\text { Type } \\
2\end{array}$ & $\begin{array}{l}\text { Insulin, DPP- } \\
4 \text { inhibitor }\end{array}$ & $\begin{array}{l}\text { DAPA } 5 \\
\text { mg }\end{array}$ & 122 & 16 & 58.3 & 8.26 & 26.89 & NR & 4 \\
\hline & & & Placebo & 60 & & 57.6 & 8.52 & 26.12 & NR & \\
\hline \multirow[t]{5}{*}{$\begin{array}{l}\text { Kaku } \\
2013^{15}\end{array}$} & $\begin{array}{l}\text { Type } \\
2\end{array}$ & None & $\begin{array}{l}\text { DAPA } 1 \\
\text { mg }\end{array}$ & 59 & 12 & 55.9 & 8.10 & NR & NR & 5 \\
\hline & & & $\begin{array}{l}\text { DAPA } \\
2.5 \mathrm{mg}\end{array}$ & 56 & & 57.7 & 7.92 & NR & NR & \\
\hline & & & $\begin{array}{l}\text { DAPA } 5 \\
\text { mg }\end{array}$ & 58 & & 58.0 & 8.05 & NR & NR & \\
\hline & & & $\begin{array}{l}\text { DAPA } 10 \\
\text { mg }\end{array}$ & 52 & & 56.5 & 8.18 & NR & NR & \\
\hline & & & Placebo & 54 & & 58.4 & 8.12 & NR & NR & \\
\hline \multirow[t]{3}{*}{$\begin{array}{l}\text { Kadowaki } \\
2014^{16}\end{array}$} & $\begin{array}{l}\text { Type } \\
2\end{array}$ & $\begin{array}{l}\text { Rescue } \\
\text { therapy }\end{array}$ & $\begin{array}{l}\text { EMPA } 5 \\
\text { mg }\end{array}$ & 110 & 12 & 57.3 & 7.92 & 26.3 & 86.5 & 4 \\
\hline & & & $\begin{array}{l}\text { EMPA } 10 \\
\mathrm{mg}\end{array}$ & 109 & & 57.9 & 7.93 & 25.3 & 85.8 & \\
\hline & & & $\begin{array}{l}\text { EMPA } 25 \\
\mathrm{mg}\end{array}$ & 109 & & 57.2 & 7.93 & 25.1 & 85.2 & \\
\hline
\end{tabular}




\begin{tabular}{|c|c|c|c|c|c|c|c|c|c|c|}
\hline Author & $\begin{array}{l}\text { Types } \\
\text { of } \\
\text { DM }\end{array}$ & $\begin{array}{l}\text { Concomitant } \\
\text { medications }\end{array}$ & $\begin{array}{l}\text { Doses } \\
\text { [mg/day] }\end{array}$ & $\mathbf{N}$ & $\begin{array}{l}\text { Duration } \\
\text { weeks }\end{array}$ & $\begin{array}{l}\text { Age } \\
\text { year }\end{array}$ & $\begin{array}{l}\text { HbA1c } \\
\text { NGSP, } \\
\%\end{array}$ & $\begin{array}{l}\text { BMI } \\
\mathrm{kg} / \mathrm{m}^{2}\end{array}$ & $\begin{array}{l}\text { eGFR } \\
\mathrm{mL} / \mathrm{min} / 1.73 \\
\mathrm{~m}^{2}\end{array}$ & $\begin{array}{l}\text { Jadad } \\
\text { Scale }\end{array}$ \\
\hline & & & $\begin{array}{l}\text { EMPA } 50 \\
\mathrm{mg}\end{array}$ & 110 & & 56.6 & 8.02 & 25.0 & 86.5 & \\
\hline & & & Placebo & 109 & & 58.7 & 7.94 & 25.6 & 84.6 & \\
\hline \multirow[t]{2}{*}{$\begin{array}{l}\text { Kawamori } \\
2018^{17}\end{array}$} & $\begin{array}{l}\text { Type } \\
2\end{array}$ & $\begin{array}{l}\text { Linagliptin, } \\
\text { Rescue } \\
\text { therapy }\end{array}$ & $\begin{array}{l}\text { EMPA } 10 \\
\mathrm{mg}\end{array}$ & 182 & $52(24)^{\star}$ & 60.0 & 8.27 & 26.0 & 89.3 & 5 \\
\hline & & & Placebo & 93 & & 59.8 & 8.36 & 26.6 & 86.3 & \\
\hline \multirow[t]{4}{*}{$\begin{array}{l}\text { Shimada } \\
2018^{18}\end{array}$} & $\begin{array}{l}\text { Type } \\
1\end{array}$ & Insulin & $\begin{array}{l}\text { EMPA } \\
2.5 \mathrm{mg}\end{array}$ & 13 & 4 & 44.2 & 8.02 & 24.4 & 88.0 & 5 \\
\hline & & & $\begin{array}{l}\text { EMPA } 10 \\
\mathrm{mg}\end{array}$ & 12 & & 44.5 & 8.12 & 22.68 & 87.0 & \\
\hline & & & $\begin{array}{l}\text { EMPA } 25 \\
\text { mg }\end{array}$ & 12 & & 46.6 & 7.89 & 22.6 & 88.8 & \\
\hline & & & Placebo & 11 & & 43.9 & 8.23 & 23.7 & 95.1 & \\
\hline \multirow[t]{2}{*}{$\begin{array}{l}\text { Ishihara } \\
2016^{19}\end{array}$} & $\begin{array}{l}\text { Type } \\
2\end{array}$ & $\begin{array}{l}\text { Insulin, DPP- } \\
4 \text { inhibitor }\end{array}$ & $\begin{array}{l}\text { IPRA } 50 \\
\text { mg }\end{array}$ & 168 & 16 & 58.7 & 8.67 & 25.61 & 83.98 & 5 \\
\hline & & & Placebo & 87 & & 59.2 & 8.62 & 26.42 & 80.11 & \\
\hline \multirow[t]{5}{*}{$\begin{array}{l}\text { Kashiwagi } \\
2014^{20}\end{array}$} & $\begin{array}{l}\text { Type } \\
2\end{array}$ & None & $\begin{array}{l}\text { IPRA } \\
12.5 \mathrm{mg}\end{array}$ & 73 & 12 & 55.3 & 8.39 & 25.6 & NR & 4 \\
\hline & & & $\begin{array}{l}\text { IPRA } 25 \\
\text { mg }\end{array}$ & 74 & & 57.0 & 8.32 & 26.2 & NR & \\
\hline & & & $\begin{array}{l}\text { IPRA } 50 \\
\text { mg }\end{array}$ & 72 & & 55.9 & 8.33 & 25.8 & NR & \\
\hline & & & $\begin{array}{l}\text { IPRA } \\
100 \mathrm{mg}\end{array}$ & 72 & & 56.0 & 8.25 & 25.9 & NR & \\
\hline & & & Placebo & 69 & & 55.2 & 8.36 & 25.1 & NR & \\
\hline \multirow[t]{2}{*}{$\begin{array}{l}\text { Kashiwagi } \\
2015 A^{21}\end{array}$} & $\begin{array}{l}\text { Type } \\
2\end{array}$ & Sulfonylurea & $\begin{array}{l}\text { IPRA } 50 \\
\text { mg }\end{array}$ & 165 & 24 & 59.6 & 8.38 & 25.81 & 84.24 & 5 \\
\hline & & & Placebo & 75 & & 59.8 & 8.34 & 24.18 & 85.87 & \\
\hline \multirow[t]{2}{*}{$\begin{array}{l}\text { Kashiwagi } \\
2015 B^{22}\end{array}$} & $\begin{array}{l}\text { Type } \\
2\end{array}$ & Pioglitazone & $\begin{array}{l}\text { IPRA } 50 \\
\text { mg }\end{array}$ & 97 & 24 & 56.2 & 8.24 & 27.11 & NR & 5 \\
\hline & & & Placebo & 54 & & 56.1 & 8.39 & 27.13 & NR & \\
\hline \multirow[t]{2}{*}{$\begin{array}{l}\text { Kashiwagi } \\
2015 C^{23}\end{array}$} & $\begin{array}{l}\text { Type } \\
2\end{array}$ & None & $\begin{array}{l}\text { IPRA } 50 \\
\text { mg }\end{array}$ & 62 & 16 & 60.6 & 8.40 & 25.3 & NR & 5 \\
\hline & & & Placebo & 67 & & 58.3 & 8.25 & 25.6 & NR & \\
\hline \multirow[t]{2}{*}{$\begin{array}{l}\text { Kashiwagi } \\
2015 D^{24}\end{array}$} & $\begin{array}{l}\text { Type } \\
2\end{array}$ & $\begin{array}{l}\text { Antidiabetic } \\
\text { agents }\end{array}$ & $\begin{array}{l}\text { IPRA } 50 \\
\text { mg }\end{array}$ & 118 & 24 & 63.9 & 7.53 & 25.84 & 60.2 & 5 \\
\hline & & & Placebo & 46 & & 65.7 & 7.55 & 24.96 & 62.7 & \\
\hline
\end{tabular}




\begin{tabular}{|c|c|c|c|c|c|c|c|c|c|c|}
\hline Author & $\begin{array}{l}\text { Types } \\
\text { of } \\
\text { DM }\end{array}$ & $\begin{array}{l}\text { Concomitant } \\
\text { medications }\end{array}$ & $\begin{array}{l}\text { Doses } \\
\text { [mg/day] }\end{array}$ & $\mathbf{N}$ & $\begin{array}{l}\text { Duration } \\
\text { weeks }\end{array}$ & $\begin{array}{l}\text { Age } \\
\text { year }\end{array}$ & $\begin{array}{l}\text { HbA1c } \\
\text { NGSP, } \\
\%\end{array}$ & $\begin{array}{l}\text { BMI } \\
\mathrm{kg} / \mathrm{m}^{2}\end{array}$ & $\begin{array}{l}\text { eGFR } \\
\mathrm{mL} / \mathrm{min} / 1.73 \\
\mathrm{~m}^{2}\end{array}$ & $\begin{array}{l}\text { Jadad } \\
\text { Scale }\end{array}$ \\
\hline \multirow[t]{2}{*}{$\begin{array}{l}\text { Kashiwagi } \\
2015 E^{25}\end{array}$} & $\begin{array}{l}\text { Type } \\
2\end{array}$ & Metformin & $\begin{array}{l}\text { IPRA } 50 \\
\text { mg }\end{array}$ & 112 & 24 & 56.2 & 8.25 & 25.96 & NR & 4 \\
\hline & & & Placebo & 56 & & 57.7 & 8.38 & 25.47 & NR & \\
\hline \multirow[t]{2}{*}{$\begin{array}{l}\text { Haneda } \\
2016^{26}\end{array}$} & $\begin{array}{l}\text { Type } \\
2\end{array}$ & Unclear & $\begin{array}{l}\text { LUSEO } \\
2.5 \mathrm{mg}\end{array}$ & 95 & 24 & 67.9 & 7.72 & 25.45 & 52.0 & 4 \\
\hline & & & Placebo & 50 & & 68.4 & 7.69 & 25.81 & 52.4 & \\
\hline \multirow[t]{2}{*}{$\begin{array}{l}\text { Seino } \\
2014 A^{27}\end{array}$} & $\begin{array}{l}\text { Type } \\
2\end{array}$ & None & $\begin{array}{l}\text { LUSEO } \\
2.5 \mathrm{mg}\end{array}$ & 79 & 24 & 58.9 & 8.14 & 25.98 & NR & 5 \\
\hline & & & Placebo & 79 & & 59.6 & 8.17 & 25.34 & NR & \\
\hline \multirow[t]{5}{*}{$\begin{array}{l}\text { Seino } \\
2014 B^{28}\end{array}$} & $\begin{array}{l}\text { Type } \\
2\end{array}$ & None & $\begin{array}{l}\text { LUSEO } 1 \\
\mathrm{mg}\end{array}$ & 55 & 12 & 58.5 & 7.77 & 24.51 & NR & 5 \\
\hline & & & $\begin{array}{l}\text { LUSEO } \\
2.5 \mathrm{mg}\end{array}$ & 56 & & 57.4 & 8.05 & 24.79 & NR & \\
\hline & & & $\begin{array}{l}\text { LUSEO } 5 \\
\mathrm{mg}\end{array}$ & 54 & & 57.3 & 7.86 & 26.43 & NR & \\
\hline & & & $\begin{array}{l}\text { LUSEO } \\
10 \mathrm{mg}\end{array}$ & 58 & & 59.6 & 7.95 & 23.36 & NR & \\
\hline & & & Placebo & 57 & & 57.1 & 7.92 & 25.15 & NR & \\
\hline \multirow[t]{4}{*}{$\begin{array}{l}\text { Seino } \\
2014 C^{29}\end{array}$} & $\begin{array}{l}\text { Type } \\
2\end{array}$ & None & $\begin{array}{l}\text { LUSEO } \\
0.5 \mathrm{mg}\end{array}$ & 60 & 12 & 55.2 & 8.16 & 25.4 & NR & 5 \\
\hline & & & $\begin{array}{l}\text { LUSEO } \\
2.5 \mathrm{mg}\end{array}$ & 61 & & 58.3 & 8.07 & 24.8 & NR & \\
\hline & & & $\begin{array}{l}\text { LUSEO } 5 \\
\mathrm{mg}\end{array}$ & 61 & & 56.8 & 8.16 & 24.5 & $\mathrm{NR}$ & \\
\hline & & & Placebo & 54 & & 57.6 & 7.88 & 25.2 & NR & \\
\hline \multirow[t]{4}{*}{$\begin{array}{l}\text { Kaku } \\
2014^{30}\end{array}$} & $\begin{array}{l}\text { Type } \\
2\end{array}$ & None & $\begin{array}{l}\text { TOFO } 10 \\
\text { mg }\end{array}$ & 57 & 24 & 58.6 & 8.45 & 25.07 & 84.90 & 5 \\
\hline & & & $\begin{array}{l}\text { TOFO } 20 \\
\mathrm{mg}\end{array}$ & 58 & & 56.6 & 8.34 & 24.99 & 86.78 & \\
\hline & & & $\begin{array}{l}\text { TOFO } 40 \\
\mathrm{mg}\end{array}$ & 58 & & 57.0 & 8.37 & 25.78 & 86.00 & \\
\hline & & & Placebo & 56 & & 56.8 & 8.41 & 26.00 & 83.78 & \\
\hline \multirow[t]{3}{*}{$\begin{array}{l}\text { Terauchi } \\
2017^{31}\end{array}$} & $\begin{array}{l}\text { Type } \\
2\end{array}$ & $\begin{array}{l}\text { Insulin, DPP- } \\
4 \text { inhibitor, }\end{array}$ & $\begin{array}{l}\text { TOFO } 20 \\
\mathrm{mg}\end{array}$ & 141 & 16 & 59.1 & 8.53 & 25.8 & 79.7 & 5 \\
\hline & & $\begin{array}{l}\text { Rescue } \\
\text { therapy }\end{array}$ & & & & & & & & \\
\hline & & & Placebo & 70 & & 56.4 & 8.40 & 26.9 & 79.5 & \\
\hline
\end{tabular}




\begin{tabular}{|c|c|c|c|c|c|c|c|c|c|c|}
\hline Author & $\begin{array}{l}\text { Types } \\
\text { of } \\
\text { DM }\end{array}$ & $\begin{array}{l}\text { Concomitant } \\
\text { medications }\end{array}$ & $\begin{array}{l}\text { Doses } \\
\text { [mg/day] }\end{array}$ & $\mathbf{N}$ & $\begin{array}{l}\text { Duration } \\
\text { weeks }\end{array}$ & $\begin{array}{l}\text { Age } \\
\text { year }\end{array}$ & $\begin{array}{l}\text { HbA1c } \\
\text { NGSP, } \\
\%\end{array}$ & $\begin{array}{l}\mathrm{BMI} \\
\mathrm{kg} / \mathrm{m}^{2}\end{array}$ & $\begin{array}{l}\text { eGFR } \\
\mathrm{mL} / \mathrm{min} / 1.73 \\
\mathrm{~m}^{2}\end{array}$ & $\begin{array}{l}\text { Jadad } \\
\text { Scale }\end{array}$ \\
\hline $\begin{array}{l}\text { SGLT2 s } \\
\text { estimate } \\
\text { LUSEO I } \\
\text { SGLT2 ir }\end{array}$ & $\begin{array}{l}\text {-gluc } \\
\text { nerul } \\
\text { ifloz } \\
\text { rs w }\end{array}$ & $\begin{array}{l}\text { o-transport } \\
\text { ration rate, } \\
\text { FO tofoglifl } \\
\text { tiated. }\end{array}$ & $\begin{array}{l}\text { BMI boc } \\
\text { A canag } \\
\text { NR not }\end{array}$ & & $\begin{array}{l}\text { X, DM } \\
\text { A dapa } \\
\text { ata we }\end{array}$ & tra & itu & $\begin{array}{l}4 \mathrm{di} \\
\text { ifloz } \\
4 \mathrm{be}\end{array}$ & $\begin{array}{l}\text { yl peptidase } \\
\text { 'A ipragliflo } \\
\text { e up-titratio }\end{array}$ & eGFR \\
\hline
\end{tabular}

Quality assessment of each RCT

The Jadad scale ${ }^{33}$ of the studies examined ranged between 4 and 5 points (Table 1). We also assessed the risk of bias of RCTs based on the Cochrane handbook ${ }^{34}$. The majority of studies were high-quality RCTs. "Low risk" was the highest in the domains of the blinding of participants and personnel and the blinding of outcome assessments. "Unclear risk" was the highest in both random sequence generation and allocation concealment. "High risk" was indicated in the definition of adverse events (other bias) (Supplementary Figure S2).

Glycemic control

Twenty-two trials were included in the meta-analysis. Statistical heterogeneity was observed among trials $\left(\mathrm{I}^{2}=90 \%\right)$. $\mathrm{HbA} 1 \mathrm{C}$ values were significantly better with SGLT2 inhibitors than with a placebo [mean difference $-0.83(95 \% \mathrm{Cl}-0.96$ to -0.70$) \%$, $p<0.00001]$, and all types of SGLT2 inhibitors showed a significant difference in the sub-group analysis. The IPRA group had the highest weight (31.5\%), whereas the DAPA and TOFO groups had the lowest weight (9.3\% each) (Supplementary Figure S3).

Hypoglycemia

Eighteen out of the 20 studies retrieved were quantified in the meta-analysis. SGLT2 inhibitors were associated with a similar risk of hypoglycemia as a placebo [risk ratio $1.16(95 \% \mathrm{Cl} 0.93$ to 1.45$), p=0.20$ ], and the IPRA group showed a significant difference in the sub-group analysis. The EMPA group had the greatest weight (39.6\%), whereas the LUSEO group had the lowest weight (3.5\%). Statistical homogeneity was observed among trials $\left(I^{2}=16 \%\right)$ (Fig. 1).

UTI

Nineteen out of the 22 studies retrieved were quantified in the meta-analysis. SGLT2 inhibitors were associated with a similar risk of UTI as a placebo [risk ratio $0.78(95 \% \mathrm{Cl} 0.47$ to 1.31$), p=0.35$ ], and no groups showed a significant difference in the sub-group analysis. The IPRA group had the greatest weight (39.6\%), whereas the TOF group had the lowest weight (5.2\%). Statistical homogeneity was observed among trials $\left(\mathrm{I}^{2}=0 \%\right.$ ) (Fig. 2).

Genital infection

Eighteen out of the 19 studies retrieved were quantified in the meta-analysis. SGLT2 inhibitors were associated with a similar risk of genital infection as a placebo [risk ratio 1.30 ( $95 \% \mathrm{Cl} 0.65$ to 2.58$), p=0.46$ ], and no groups showed a significant difference in the sub-group analysis. The IPRA group had the greatest weight (30.2\%), whereas the TOFO group had the lowest weight (9.3\%). Statistical homogeneity was observed among trials $\left(I^{2}=0 \%\right)($ Fig. 3$)$.

Hypovolemia

Seven out of the 11 studies retrieved were quantified in the meta-analysis. SGLT2 inhibitors were associated with a similar risk of hypovolemia as a placebo [risk ratio $1.12(95 \% \mathrm{Cl} 0.48$ to 2.61$), p=0.80$ ], and no groups showed a significant difference in 
the sub-group analysis. The LUSEO group had the greatest weight (32.2\%), whereas the CANA group had the lowest weight (12.7\%). Statistical homogeneity was observed among trials $\left(I^{2}=0 \%\right)$ (Fig. 4).

\section{Fracture}

Four studies were quantified in the meta-analysis. SGLT2 inhibitors were associated with a similar risk of fracture as a placebo [risk ratio 0.85 ( $95 \% \mathrm{Cl} 0.20$ to 3.61$), p=0.82$ ], and no groups showed a significant difference in the sub-group analysis. The EMPA group had the greatest weight (40.4\%), whereas the TOFO group had the lowest weight $(19.8 \%)$. Statistical homogeneity was observed among trials $\left(I^{2}=5 \%\right)($ Fig. 5$)$.

Publication bias

Three outcomes (hypoglycemia, UTI, and genital infection) included more than 10 RCTs. Funnel plots visually detected a publication bias in all four outcomes (Supplementary Figures S4-6).

Additional analyses

The sub-group analysis including only patients with type 2 DM showed that the risk of hypoglycemia was higher with SGLT2 inhibitors than with a placebo. This was not consistent with the results of the main analyses (Supplementary Table S1).

\section{Discussion}

We herein conducted a systematic review and meta-analysis to summarize the available literature and appraise the safety profiles of SGLT2 inhibitors in Japanese patients with DM. The results obtained revealed that SGLT2 inhibitors were associated with similar risks of hypoglycemia, UTI, genital infection, hypovolemia, and fracture as a placebo. The safety data of the present analysis had negligible heterogeneity $\left(I^{2} \leq 18 \%\right)$.

The result showing that SGLT2 inhibitors had a similar risk of hypoglycemia as a placebo [risk ratio $1.16(95 \% \mathrm{Cl} 0.93$ to 1.45$)$, $\mathrm{I}^{2}=16 \%$ ] was consistent with the findings of a previous study ${ }^{35}$; however, their data differed from the present study, which partially included patients with type 1 DM. Moreover, SGLT2 inhibitors as monotherapy among Asian and non-Asian patients with type 2 DM did not increase the risk of hypoglycemia 7,35 . The addition of combination therapies to an oral hypoglycemic agent(s) or insulin is known to generally increase the risk of hypoglycemia; however, multiple meta-analyses including patients with type $1 \mathrm{DM}$ and with no restrictions in race/ethnicity revealed that even dual combination therapy with a SGLT2 inhibitor and insulin did not increase the risk of hypoglycemia over that with a placebo $2,3,36$. This can be attributed to the insulinindependent antihyperglycemic effects of SGLT2 inhibitors, rather than racial or ethnic differences.

The present study demonstrated that SGLT2 inhibitors had a similar risk of UTI [risk ratio $0.78(95 \% \mathrm{Cl} 0.47$ to 1.31$)$ ] as a placebo. This result supports the findings of two previous studies including Asian patients with type $2 \mathrm{DM}^{7,35}$. Furthermore, a larger meta-analysis of more than 100 RCTs and with no racial or ethnic restrictions showed that the risk of UTI was similar between SGLT2 inhibitors and a placebo ${ }^{37}$. A large population-based cohort study using U.S. databases of patients with employer-based insurance also reported that in comparisons with glucagon-like peptide-1 receptor agonists, treatments with SGLT2 inhibitors were not associated with the risk of severe and non-severe UTI ${ }^{38}$. These findings suggest that SGLT2 inhibitors are unlikely to increase the risk of UTI regardless of whether patients are Asians or non-Asians. Two previous metaanalyses of Asian populations showed that SGLT2 inhibitors consistently increased the risk of genital infection 7,35. Furthermore, a few meta-analyses with long-term follow-ups reported an increased risk of genital infection with SGLT2 inhibitors ${ }^{39,40}$. One possible explanation for the inconsistency between the present results and these findings is that the RCTs retrieved had relatively short-term follow-ups (at most 24 weeks). Three meta-analyses consistently showed that a treatment with DAPA was likely to dose-dependently increase the risk of UTI and genital infection $37,39,41$; however, DAPA did not increase the risk of either event in sub-analyses (Figs. 2,3). 
The present results showed that in comparisons with a placebo, SGLT2 inhibitors had a similar risk of hypovolemia [risk ratio $1.12(95 \% \mathrm{Cl} 0.48$ to 2.61$)$ ]. A previous study on East Asian patients with type $2 \mathrm{DM}$ found no significant difference in the risk of hypotension between SGLT2 inhibitors and a placebo ${ }^{35}$. In contrast, one RCT with a long-term follow-up of more than 100 weeks among mainly Caucasian patients with type $2 \mathrm{DM}$ showed that the prevalence of volume depletion-related adverse events was three-fold higher with SGLT2 inhibitors than with a placebo ${ }^{4}$. Since they reported that these events with SGLT2 inhibitors generally occurred within 26 weeks and that a longer exposure to SGLT2 inhibitors may have resulted in a higher incidence of these events ${ }^{4}$, the incidence of hypovolemia in a short-term follow-up may be lower among Japanese patients treated with SGLT2 inhibitors than among Caucasian patients; however, these data need to be interpreted with caution because the definition of hypovolemia or volume depletion varied among the studies retrieved. Moreover, a meta-analysis of patients with type 2 DM and chronic kidney disease showed a slightly elevated risk of hypovolemia with SGLT2 inhibitors 42 . Further studies with a standardized definition of adverse events and involving more diverse populations are needed to support the present results.

The present analysis indicated that SGLT2 inhibitors were associated with a similar risk of fracture as a placebo [risk ratio 0.85 (95\% Cl 0.20 to 3.61)] (Supplementary Table S1). This was consistent with a meta-analysis of East Asian patients ${ }^{35}$ and with a network meta-analysis including approximately $80 \%$ Caucasian patients ${ }^{43}$; however, a sub-analysis of the network meta-analysis showed the opposite findings, namely, Asian populations had a slightly higher risk of fracture ${ }^{43}$. The reason for this disparity is unclear. The treatment duration of SGLT2 inhibitors continuously increased the risk of fracture ${ }^{44}$. Cohort or case-control studies rather than RCTs with short-term durations are generally more likely to show long-term or rare adverse events. Therefore, the duration of the follow-up in our analysis was too short to assess the risk of fracture; previous reports that evaluated the risk of fracture had the same limitation as our analysis $35,43,45$. Additionally, our fracture outcome did not include all types of SGLT2 inhibitors. Collectively, the present results and previous findings indicate that more RCTs with longterm follow-ups and individual SGLT2 inhibitors are needed in the future.

Our sub-analysis including only type 2 DM indicated that the risk of hypoglycemia was higher with SGLT2 inhibitors than with a placebo [RR $1.30(95 \% \mathrm{Cl} 1.01$ to 1.65$)$ ]. This result was partially in line with the findings of an earlier meta-analysis of Asian patients with type $2 \mathrm{DM}^{7}$. Since the excluded RCT ${ }^{18}$ had the shortest study duration of 4 weeks and the greatest weight of $38.5 \%$ in the hypoglycemia outcome (Fig. 1), the RCT may have affected this result.

The present study has some strengths. To the best of our knowledge, this is the first systematic literature review and metaanalysis to appraise the safety profiles of SGLT2 inhibitors in Japanese patients with DM. Furthermore, the safety data of our analyses consistently had negligible heterogeneity $\left(I^{2} \leq 18 \%\right)$ and the majority of the studies retrieved were high-quality RCTs (Supplementary Figure S2). However, the present study also had some limitations. It may have had a publication bias because we only retrieved published studies. We were unable to rule out the impact of anti-hyperglycemic agents or to exclude type 1 DM patients; the former is because some studies included patients who were treated with an oral hypoglycemic agent or insulin, while the latter is due to one RCT including patients with type $1 \mathrm{DM}^{18}$. Therefore, we were only able to evaluate the safety profiles of SGLT2 inhibitors in all Japanese patients with DM; however, we confirmed that the results of the subanalysis of patients with type $2 \mathrm{DM}$ only were consistent with those of the main analyses among all patients with DM (Supplementary Table S1). Other limitations are that the RCTs retrieved did not always set the adverse events that we evaluated as their primary endpoint, and also that the numbers of different types of SGLT2 inhibitors pooled were unbalanced. Therefore, our data may be biased.

\section{Conclusion}

The present results suggest that in comparisons with a placebo, SGLT2 inhibitors were associated with similar risks of hypoglycemia, UTI, genital infection, hypovolemia, and fracture. Treatments with SGLT2 inhibitors among Japanese patients with DM suggest favorable safety profiles. However, further evidence from studies with a longer duration, involving more diverse populations, or including individual SGLT2 inhibitors is needed to resolve the limitations of the present study. We 
consider the present results to be informative for SGLT2 inhibitors users with concerns regarding the safety profiles of SGLT2 inhibitors.

\section{Methods}

Search strategies for the identification of RCTs

We searched the electronic databases MEDLINE, The Cochrane Central Register of Controlled Trials (CENTRAL), and Japana Centra Revuo Medicina (Ichushi-web) for studies from their inception through to 26 August 2019. We included six types of SGLT2 inhibitors: CANA, DAPA, EMPA, IPRA, LUSEO, and TOFO. We used individual SGLT2 inhibitor names, alternative names, "sodium-glucose transporter 2", and "SGLT2 inhibitors" as search terms. We restricted our search to "randomized controlled trial" in these electronic databases. A reference search was also implemented from relevant studies in order to identify more RCTs. The study search was undertaken independently by two authors (SK and JM). Any discrepancies were settled by discussions between the two assessors.

Management for data extraction

We did not impose any language restriction. Trials were included if they were RCTs (1) comparing the effects of SGLT2 inhibitors with a placebo in Japanese patients with DM who were 18 years or older, and (2) reporting HbA1c and at least one adverse event. We excluded cross-over trials, RCTs with no information available on race/ethnicity, and RCTs involving healthy subjects. We extracted data on the types of DM, trial population, co-interventions as medication use, the daily dose of each SGLT2 inhibitor, and baseline profiles: HbA1c, body mass index (BMI), age, and the estimated glomerular filtration rate (eGFR). The safety outcomes of interest were as follows: hypoglycemia, UTI, genital infection, hypovolemia, and fracture. The term UTI included cystitis. Other definitions of safety outcomes were followed as defined by each author of the study.

Quality assessment of each RCT

Study quality was rated using the Jadad scale and risk of bias tool. The Jadad scale is used to evaluate the appropriateness of the randomization technique, the method used for double-masking, and descriptions of dropouts or withdrawals ${ }^{34}$. The scale ranges between zero and five. We included studies that scored 4 points or higher in the analysis. The risk of bias for the studies was assessed using the Cochrane Collaboration's tool ${ }^{34}$. Seven items were examined for the risk of bias: random sequence generation, allocation concealment, the blinding of participants and personnel, blinding of outcome assessments, incomplete outcome data, free of selective reporting, and quality evidence on safety parameters as other sources of bias. Each of the seven items was scored as a "low risk", "unclear risk", or "high risk".

Data synthesis

We calculated the risk ratio with $95 \% \mathrm{Cl}$ for each safety outcome. The heterogeneity of each outcome was evaluated using chisquared and $\mathrm{I}^{2}$ statistics. A value of $40 \%$ or more was defined to represent marked heterogeneity ${ }^{34}$. We used a random-effects model (the Mantel-Haenszel method ${ }^{46}$ ) to more conservatively assess outcomes. In the meta-analysis, multiple SGLT2 inhibitor groups in a single trial were combined into a single group ${ }^{34}$. Subgroup analyses were performed by including only patients with type $1 \mathrm{DM}$ and only patients who were treated with a SGLT2 inhibitor as monotherapy. We drew a funnel plot to assess publication bias visually when there were 10 RCTs or more in the meta-analysis ${ }^{34}$. All statistical analyses were performed with review manager 5.3 software (The Nordic Cochrane Centre, The Cochrane Collaboration, 2014). A P value less than 0.05 was considered to be significant.

\section{Declarations}

Author contributions: JM conceived and designed the study. JM and SK performed the systematic review of the literature. JM and SK analyzed and interpreted the data. JM wrote the manuscript. 
RK contributed to data interpretation and the Discussion section. All authors approved the final manuscript.

Additional information

Competing interests: The author(s) declare no competing interests.

\section{References}

1. Monami, M., Nardini, C. \& Mannucci, E. Efficacy and safety of sodium glucose co-transport-2 inhibitors in type 2 diabetes: a meta-analysis of randomized clinical trials. Diabetes Obes. Metab. 16, 457-66 (2014).

2. Chen, J. et al. The efficacy and safety of SGLT2 inhibitors for adjunctive treatment of type 1 diabetes: a systematic review and meta-analysis. Sci. Rep. 7, 44128; 10.1038/srep44128 (2017).

3. Yamada, T., Shojima, N., Noma, H., Yamauchi, T. \& Kadowaki, T. Sodium-glucose co-transporter-2 inhibitors as add-on therapy to insulin for type 1 diabetes mellitus: Systematic review and meta-analysis of randomized controlled trials. Diabetes Obes. Metab. 20, 1755-1761 (2018).

4. Bode, B. et al. Long-term efficacy and safety of canagliflozin over 104 weeks in patients aged 55-80 years with type 2 diabetes. Diabetes Obes. Metab. 17, 294-303 (2015).

5. Yale, J. F. et al. Efficacy and safety of canagliflozin in subjects with type 2 diabetes and chronic kidney disease. Diabetes Obes. Metab. 15, 463-473 (2013).

6. Ji, L. et al. Canagliflozin in Asian patients with type 2 diabetes on metformin alone or metformin in combination with sulphonylurea. Diabetes Obes. Metab. 17, 23-31 (2015).

7. Cai, X. et al. No disparity of the efficacy and all-cause mortality between Asian and non-Asian type 2 diabetes patients with sodium-glucose cotransporter 2 inhibitors treatment: A meta-analysis. J. Diabetes Investig. 9, 850-861 (2018).

8. Mukai, J., Yoshiyama, A. \& Kubota, R. Clinical relevance between sodium-glucose co-transporter 2 inhibitors and lipid profiles in Asian patients with type 2 diabetes mellitus: a systematic review with a meta-analysis of randomized controlled trials. J. Pharm. Health Care Sci. 6, 4; 10.1186/s40780-020-00160-0 (2020)

9. McDowell, S. E., Coleman J. J. \& Ferner, R. E. Systematic review and meta-analysis of ethnic differences in risks of adverse reactions to drugs used in cardiovascular medicine. BMJ. 332, 1177-1181 (2006).

10. Inagaki, N. et al. Efficacy and safety of canagliflozin in Japanese patients with type 2 diabetes: a randomized, doubleblind, placebo-controlled, 12-week study. Diabetes Obes. Metab. 15, 1136-1145 (2013).

11. Inagaki, N. et al. Efficacy and safety of canagliflozin monotherapy in Japanese patients with type 2 diabetes inadequately controlled with diet and exercise: a 24-week, randomized, double-blind, placebo-controlled, Phase III study. Expert Opinion on Pharmacotherapy. 15, 1501-1515 (2014).

12. Inagaki, N. et al. Efficacy and safety of canagliflozin in combination with insulin: a double-blind, randomized, placebocontrolled study in Japanese patients with type 2 diabetes mellitus. Cardiovasc. Diabetol. 15, 89; 10.1186/s12933-0160407-4 (2016).

13. Kadowaki, T. et al. Efficacy and safety of canagliflozin as add-on therapy to teneligliptin in Japanese patients with type 2 diabetes mellitus: Results of a 24-week, randomized, double-blind, placebo-controlled trial. Diabetes Obes. Metab. 19, 874-882 (2017).

14. Araki, E. et al. Efficacy and safety of dapagliflozin in addition to insulin therapy in Japanese patients with type 2 diabetes: Results of the interim analysis of 16-week double-blind treatment period. J. Diabetes Investig. 7, 555-564 (2016).

15. Kaku, K. et al. Efficacy and safety of dapagliflozin as a monotherapy for type 2 diabetes mellitus in Japanese patients with inadequate glycaemic control: a phase II multicentre, randomized, double-blind, placebo-controlled trial. Diabetes Obes. Metab. 15, 432-440 (2013).

16. Kadowaki, T. et al. Empagliflozin monotherapy in Japanese patients with type 2 diabetes mellitus: a randomized, 12-week, double-blind, placebo-controlled, phase II trial. Adv. Ther. 31, 621-638 (2014). 
17. Kawamori, R. et al. Empagliflozin as add-on to linagliptin in a fixed-dose combination in Japanese patients with type 2 diabetes: Glycaemic efficacy and safety profile in a 52-week, randomized, placebo-controlled trial. Diabetes Obes. Metab. 20, 2200-2209 (2018).

18. Shimada, A. et al. Empagliflozin as adjunct to insulin in Japanese participants with type 1 diabetes: Results of a 4-week, double-blind, randomized, placebo-controlled phase 2 trial. Diabetes Obes. Metab. 20, 2190-2199 (2018).

19. Ishihara, H., Yamaguchi, S., Nakao, I., Okitsu, A. \& Asahina, S. Efficacy and safety of ipragliflozin as add-on therapy to insulin in Japanese patients with type 2 diabetes mellitus (IOLITE): a multi-centre, randomized, placebo-controlled, doubleblind study. Diabetes Obes. Metab. 18, 1207-1216 (2016).

20. Kashiwagi, A., Kazuta, K., Yoshida, S. \& Nagase, I. Randomized, placebo-controlled, double-blind glycemic control trial of novel sodium-dependent glucose cotransporter 2 inhibitor ipragliflozin in Japanese patients with type 2 diabetes mellitus. J. Diabetes Investig. 5, 382-391 (2014).

21. Kashiwagi, A. et al. Efficacy and safety of ipragliflozin as an add-on to a sulfonylurea in Japanese patients with inadequately controlled type 2 diabetes: results of the randomized, placebo-controlled, double-blind, phase III EMIT study. Diabetol. Int. 6, 125-138 (2015).

22. Kashiwagi, A. et al. Efficacy and safety of ipragliflozin as an add-on to pioglitazone in Japanese patients with inadequately controlled type 2 diabetes: a randomized, double-blind, placebo-controlled study (the SPOTLIGHT study). Diabetol. Int. 6, 104-116 (2015).

23. Kashiwagi, A. et al. Ipragliflozin improves glycemic control in Japanese patients with type 2 diabetes mellitus: the BRIGHTEN study. Diabetol. Int. 6, 8-18 (2015).

24. Kashiwagi, A. et al. A randomized, double-blind, placebo-controlled study on long-term efficacy and safety of ipragliflozin treatment in patients with type 2 diabetes mellitus and renal impairment: results of the long-term ASP1941 safety evaluation in patients with type 2 diabetes with renal impairment (LANTERN) study. Diabetes Obes. Metab. 17, 152-160 (2015).

25. Kashiwagi, A. et al. Ipragliflozin in combination with metformin for the treatment of Japanese patients with type 2 diabetes: ILLUMINATE, a randomized, double-blind, placebo-controlled study. Diabetes Obes. Metab. 17, 304-308 (2015).

26. Haneda, M. et al. Influence of Renal Function on the 52-Week Efficacy and Safety of the Sodium Glucose Cotransporter 2 Inhibitor Luseogliflozin in Japanese Patients with Type 2 Diabetes Mellitus. Clin. Ther. 38, 66-88 (2016).

27. Seino, Y. et al. Efficacy and safety of luseogliflozin as monotherapy in Japanese patients with type 2 diabetes mellitus: a randomized, double-blind, placebo-controlled, phase 3 study. Curr. Med. Res. Opin. 30, 1245-1255 (2014).

28. Seino, Y. et al. Dose-finding study of luseogliflozin in Japanese patients with type 2 diabetes mellitus: a 12-week, randomized, double-blind, placebo-controlled, phase II study. Curr. Med. Res. Opin. 30, 1231-1244 (2014).

29. Seino, Y., Sasaki, T., Fukatsu, A., Sakai, S. \& Samukawa, Y. Efficacy and safety of luseogliflozin monotherapy in Japanese patients with type 2 diabetes mellitus: a 12-week, randomized, placebo-controlled, phase ll study. Curr. Med. Res. Opin. 30, 1219-1230 (2014).

30. Kaku, K. et al. Efficacy and safety of monotherapy with the novel sodium/glucose cotransporter-2 inhibitor tofogliflozin in Japanese patients with type 2 diabetes mellitus: a combined Phase 2 and 3 randomized, placebo-controlled, double-blind, parallel-group comparative study. Cardiovasc. Diabetol. 13, 65; 10.1186/1475-2840-13-65 (2014).

31. Terauchi, Y., Tamura, M., Senda, M., Gunji, R. \& Kaku, K. Efficacy and safety of tofogliflozin in Japanese patients with type 2 diabetes mellitus with inadequate glycaemic control on insulin therapy (J-STEP/INS): Results of a 16-week randomized, double-blind, placebo-controlled multicentre trial. Diabetes Obes. Metab. 19, 1397-1407 (2017).

32. Moher, D., Liberati, A., Tetzlaff, J. \& Altman, D. G. Preferred reporting items for systematic reviews and meta-analyses: the PRISMA statement. Ann. Intern. Med. 151, 264-269 (2009).

33. Jadad, A. R. et al. Assessing the quality of reports of randomized clinical trials: is blinding necessary? Control Clin. Trials. 17, 1-12 (1996). 
34. Higgins, J. P. T. \& Green, S. The Cochrane Handbook for Systematic Reviews of Interventions http://handbook.cochrane.org/ (2011).

35. Yang, L., Zhang, L., He, H., Zhang, M. \& An, Z. Efficacy and Safety of Sodium-Glucose Cotransporter 2 Inhibitors in East Asians with Type 2 Diabetes: A Systematic Review and Meta-Analysis. Diabetes Ther. 10, 1921-1934 (2019).

36. Lu, J., Tang, L., Meng, H., Zhao, J. \& Liang, Y. Effects of sodium-glucose cotransporter (SGLT) inhibitors in addition to insulin therapy on glucose control and safety outcomes in adults with type 1 diabetes: A meta-analysis of randomized controlled trials. Diabetes Metab. Res. Rev. 35, e3169; 10.1002/dmrr.3169 (2019).

37. Donnan, J. R. et al. Comparative safety of the sodium glucose co-transporter 2 (SGLT2) inhibitors: a systematic review and meta-analysis. BMJ Open.9, e022577; 10.1136/bmjopen-2018-022577 (2019).

38. Dave, C. V. et al. Sodium-Glucose Cotransporter-2 Inhibitors and the Risk for Severe Urinary Tract Infections: A PopulationBased Cohort Study. Ann. Intern. Med. 171, 248-256 (2019).

39. Li, D. et al. Urinary tract and genital infections in patients with type 2 diabetes treated with sodium-glucose co-transporter 2 inhibitors: A meta-analysis of randomized controlled trials. Diabetes Obes. Metab. 19, 348-355 (2017).

40. Liu, X. Y., Zhang, N., Chen, R., Zhao, J. G. \& Yu, P. Efficacy and safety of sodium-glucose cotransporter 2 inhibitors in type 2 diabetes: a meta-analysis of randomized controlled trials for 1 to 2 years. J. Diabetes Complications. 29, 1295-303 (2015).

41. Feng, M. et al. Efficacy and safety of dapagliflozin as monotherapy in patients with type 2 diabetes mellitus: A metaanalysis of randomized controlled trials. Medicine (Baltimore). 98, e16575; 10.1097/MD.0000000000016575 (2019).

42. Toyama, T. et al. Effect of SGLT2 inhibitors on cardiovascular, renal and safety outcomes in patients with type 2 diabetes mellitus and chronic kidney disease: A systematic review and meta-analysis. Diabetes Obes. Metab. 21, 1237-1250 (2019).

43. Tang, H. L. et al. Lack of evidence for a harmful effect of sodium-glucose co-transporter 2 (SGLT2) inhibitors on fracture risk among type 2 diabetes patients: a network and cumulative meta-analysis of randomized controlled trials. Diabetes Obes. Metab. 18, 1199-1206 (2016).

44. Watts, N. B. et al. Effects of Canagliflozin on Fracture Risk in Patients with Type 2 Diabetes Mellitus. J. Clin. Endocrinol. Metab. 101, 157-166 (2016).

45. Ruanpeng, D., Ungprasert, P., Sangtian, J. \& Harindhanavudhi, T. Sodium-glucose cotransporter 2 (SGLT2) inhibitors and fracture risk in patients with type 2 diabetes mellitus: A meta-analysis. Diabetes Metab. Res. Rev. 33; 10.1002/dmrr.2903 (2017).

46. Mantel, N. \& Haenszel, W. Statistical aspects of the analysis of data from retrospective studies of disease. Journal of the National Cancer Institute. 22, 719-748 (1959).

\section{Figures}


SGLT2 inhibitors placebo Risk Ratio

Random, $95 \% \mathrm{Cl}$

Risk Ratio



\section{Figure 1}

Forest plot for the risk of hypoglycemia Abbreviations: CANA, canagliflozin; DAPA, dapagliflozin; EMPA, empagliflozin; IPRA, ipragliflozin; LUSEO, luseogliflozin; TOFO, tofogliflozin; SGLT2, sodium-glucose co-transporter 2. 
SGLT2 inhibitors placebo

Risk Ratio

Risk Ratio

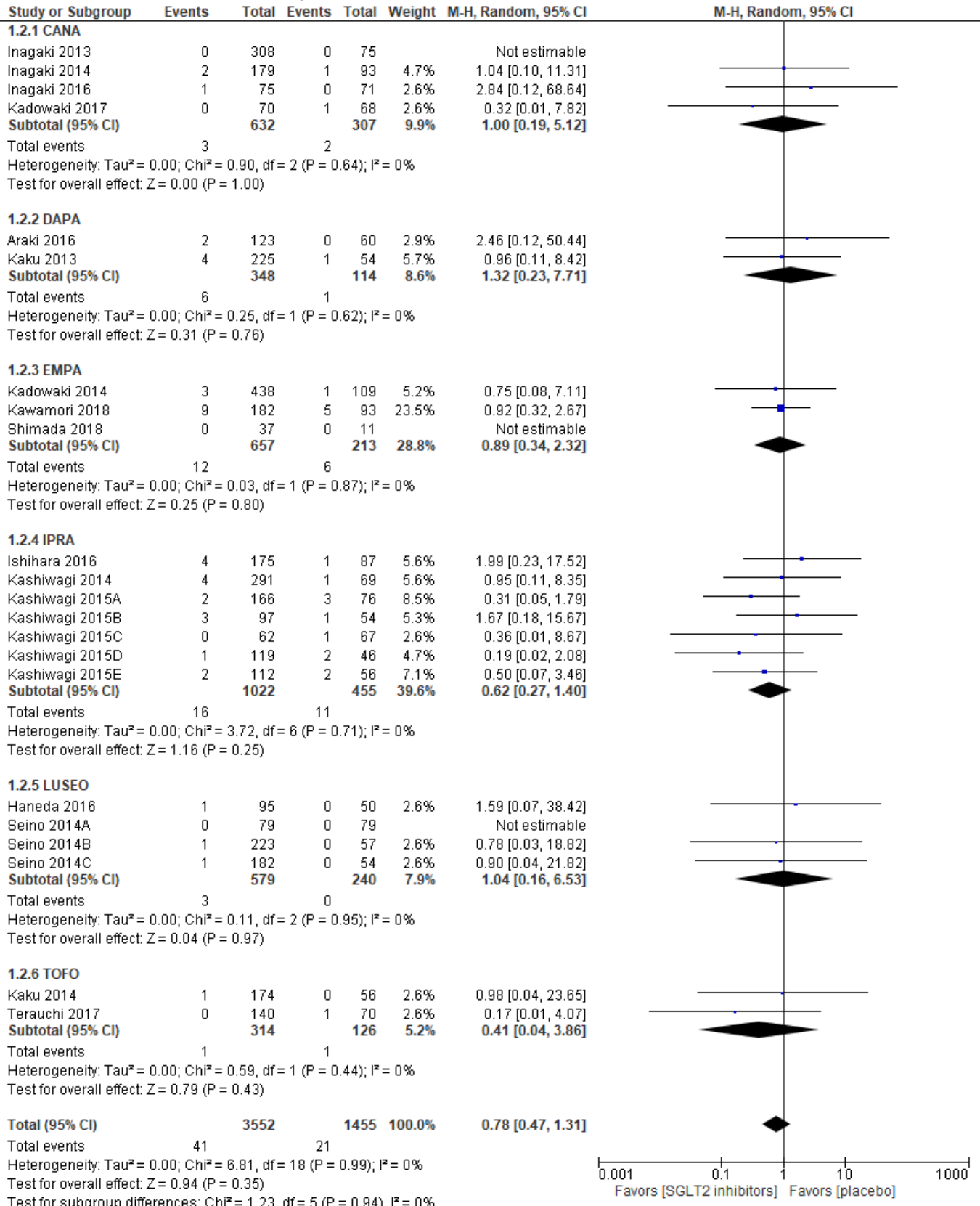

\section{Figure 2}

Forest plot for the risk of urinary tract infection Abbreviations: CANA, canagliflozin; DAPA, dapagliflozin; EMPA, empagliflozin; IPRA, ipragliflozin; LUSEO, luseogliflozin; TOFO, tofogliflozin; SGLT2, sodium-glucose co-transporter 2. 
SGLT2 inhibitors placebo Risk Ratio $\quad$ Risk Ratio



\section{Figure 3}

Forest plot for the risk of genital infection Abbreviations: CANA, canagliflozin; DAPA, dapagliflozin; EMPA, empagliflozin; IPRA, ipragliflozin; LUSEO, luseogliflozin; TOFO, tofogliflozin; SGLT2, sodium-glucose co-transporter 2. 


$\begin{array}{lrrrrrr}\text { 1.5.1 CANA } & & & & & & \\ \text { Inagaki 2014 } & 2 & 179 & 1 & 93 & 12.7 \% & 1.04[0.10,11.31] \\ \text { Inagaki } 2016 & 0 & 75 & 0 & 71 & & \text { Not estimable } \\ \text { Subtotal }(95 \% \mathrm{CI}) & & 254 & & \mathbf{1 6 4} & \mathbf{1 2 . 7 \%} & \mathbf{1 . 0 4}[0.10, \mathbf{1 1 . 3 1 ]} \\ \text { Total events } & 2 & & 1 & & & \end{array}$

Heterogeneity: Not applicable

Test for overall effect: $Z=0.03(P=0.97)$

\subsubsection{DAPA}

Kaku 2013

Subtotal $(95 \% \mathrm{Cl})$

Total events

$\begin{array}{llll}0 & 225 & 0 & 54 \\ & 225 & & 54 \\ 0 & & 0 & \end{array}$

Not estimable

Heterogeneity: Not applicable

Test for overall effect: Not applicable

\subsubsection{EMPA}

Kadowaki 2014

Kawamori 2018

Shimada 2018

Subtotal $(95 \% \mathrm{CI})$

Total events

Heterogeneity: $\operatorname{Tau}^{2}=0.00 ; \mathrm{Chi}^{2}=0.00, \mathrm{df}=1(\mathrm{P}=0.99) ;\left.\right|^{2}=0 \%$

Test for overall effect: $Z=0.74(P=0.46)$

\subsubsection{LUSEO}

Haneda 2016

Seino 2014A

Seino 2014B

Seino $2014 \mathrm{C}$

Subtotal $(95 \% \mathrm{Cl})$

Total events

Heterogeneity: $\operatorname{Tau}^{2}=0.26 ; \mathrm{Chi}^{2}=2.28, \mathrm{df}=2(\mathrm{P}=0.32) ; \mathrm{I}^{2}=12 \%$

Test for overall effect: $Z=0.32(P=0.75)$

\subsubsection{TOFO}

Terauchi 2017

Subtotal $(95 \% \mathrm{Cl})$

Total events

Heterogeneity: Not applicable

Test for overall effect: $Z=1.34(P=0.18)$

Total $(95 \% \mathrm{Cl})$

1855

Total events

24

Heterogeneity: $\operatorname{Tau}^{2}=0.00 ; \mathrm{Chi}^{2}=4.64, \mathrm{df}=6(\mathrm{P}=0.59) ; \mathrm{I}^{2}=0 \%$

Test for overall effect: $Z=0.26(P=0.80)$

Test for subqroup differences: $\mathrm{Chi}^{2}=2.39, \mathrm{df}=3(\mathrm{P}=0.50), \mathrm{I}^{2}=0 \%$
$0.50[0.05,5.44]$

$0.51[0.03,8.08]$

Not estimable

$0.50[0.08,3.07]$

\section{Figure 4}

$0.11[0.01,2.17]$

Not estimable

$1.53[0.19,12.49]$

$1.50[0.07,30.84]$

$0.76[0.15,3.86]$

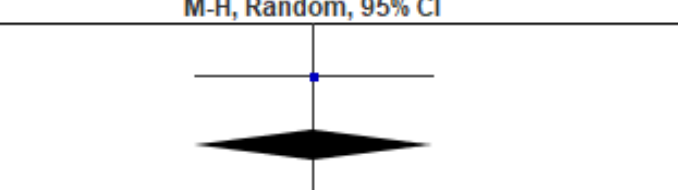

Not estimable 


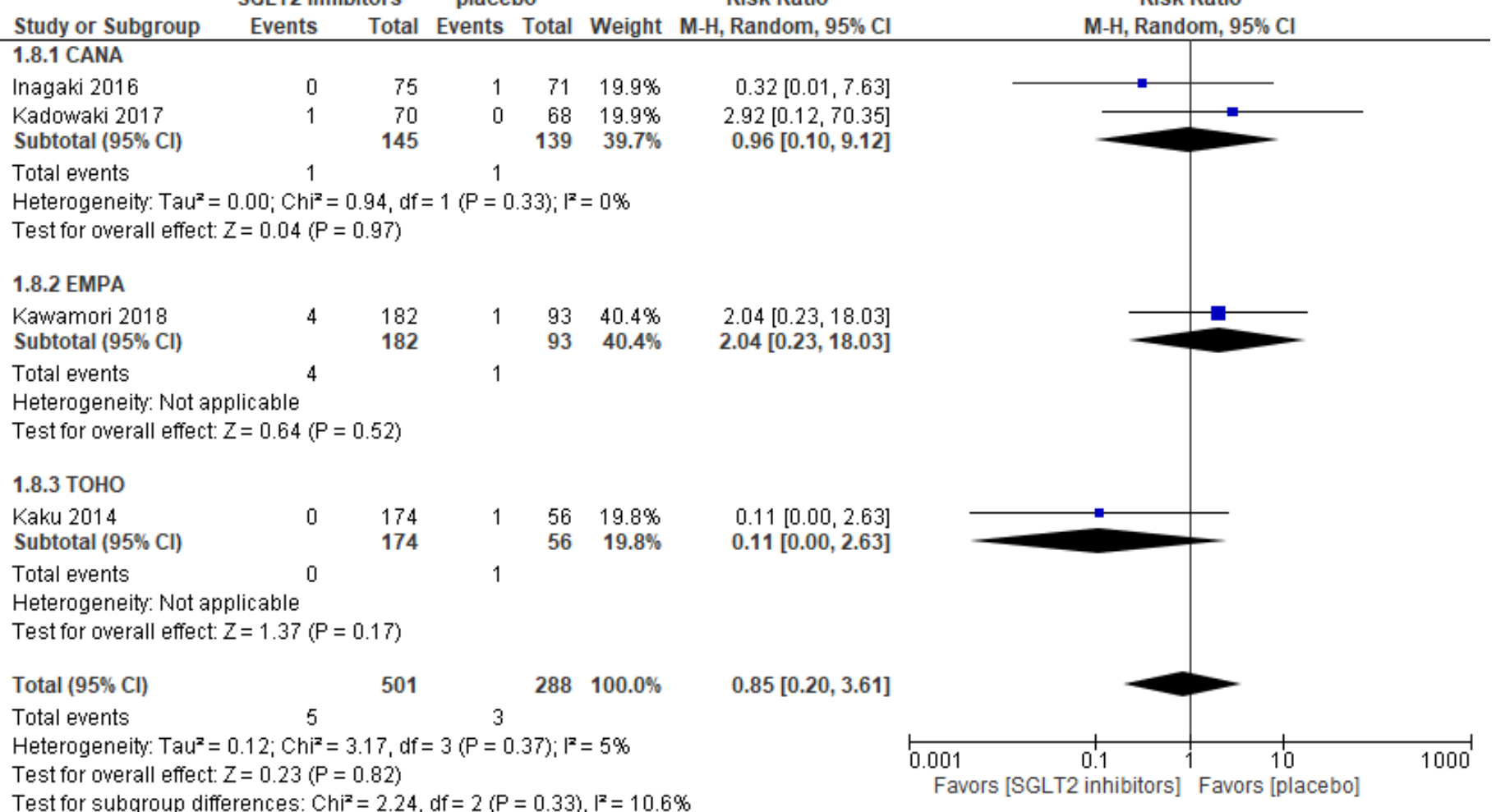

\section{Figure 5}

Forest plot for the risk of fracture Abbreviations: CANA, canagliflozin; EMPA, empagliflozin; TOFO, tofogliflozin; SGLT2, sodium-glucose co-transporter 2.

\section{Supplementary Files}

This is a list of supplementary files associated with this preprint. Click to download.

- Supplementaryfiles20210310.docx 